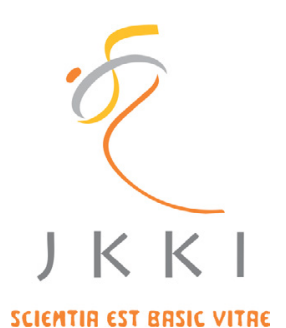

\title{
Jurnal Kedokteran dan Kesehatan Indonesia
}

Indonesian Journal of Medicine and Health

Journal homepage : www.journal.uii.ac.id/index.php/JKKI

\section{The effect of kersen's skin infusion (Muntingia calabura L.) on blood uric acid levels of the rats (Rattus novergicus)}

\author{
Asril Burhan*1, Usmar², Zulham ${ }^{1}$, and Ana Andarwiyati ${ }^{3}$, \\ ${ }^{1}$ Akademi Kebangsaan Farmasi Makassar, Makassar, Indonesia \\ ${ }^{2}$ Universitas Hasanuddin, Makassar, Indonesia \\ ${ }^{3}$ Sekolah Tinggi Ilmu Farmasi Makassar, Makassar, Indonesia
}

Original Article

\begin{tabular}{|c|c|}
\hline & ABSTRACT \\
\hline ARTICLE INFO & \\
\hline $\begin{array}{l}\text { Keywords: } \\
\text { Ripe Kersen's, } \\
\text { Muntingia calabura L., } \\
\text { uric acid, } \\
\text { Rats, } \\
\text { Rattus novergicus }\end{array}$ & $\begin{array}{l}\text { enzymatic reshuffle of body cells from dinucleotide or ribonucleotide acids. } \\
\text { High uric acid levels can be settled in the central joints and mesenchymal } \\
\text { tissues such as the kidney. } \\
\text { Objective: To determine an effect of administering the Kersen's (Muntingia } \\
\text { calabura L.) ripe skin infusion against uric acid levels in the rats which }\end{array}$ \\
\hline $\begin{array}{l}\text { *Corresponding author: } \\
\text { asrilburhan@gmail.com }\end{array}$ & $\begin{array}{l}\text { have been induced with caffeine. } \\
\text { Methods: Eighteen rats was divided into six groups, i.e. three as a control }\end{array}$ \\
\hline $\begin{array}{l}\text { DOI : } 10.20885 / J K K I . V o l 9 . I s s 3 . a r t 7 \\
\text { History: } \\
\text { Received: March 21, } 2018 \\
\text { Accepted: September 10, } 2018 \\
\text { Online: December 31, 2018 }\end{array}$ & $\begin{array}{l}\text { group (negative, positive and normal) and three as a treatment group } \\
(0,5 \%, 1 \% \text {, and } 2 \% \text { doses). The measurements of blood uric acid levels } \\
\text { were performed before induction, after induction and after treatment on } \\
9^{\text {th }}, 12^{\text {nd }} \text {, and } 15^{\text {th }} \text { days. }\end{array}$ \\
\hline $\begin{array}{l}\text { Copyright @2018 Authors. } \\
\text { This is an open access article } \\
\text { distributed under the terms } \\
\text { of the Creative Commons At- } \\
\text { tribution-NonCommercial } 4.0 \\
\text { International Licence (http:// } \\
\text { creativecommons.org/licences/ } \\
\text { by-nc/4.0/). }\end{array}$ & $\begin{array}{l}\text { administered by ripe Kersen's fruit skin infusion at } 1 \% \text { with } 3,43 \mathrm{mg} / \mathrm{dL} \\
\text { and } 2 \% \text { with } 3.32 \mathrm{mg} / \mathrm{dL} \text { doses. However, this reduction is not equivalent } \\
\text { to the effect of allopurinol control decreased at } 2.9 \mathrm{mg} / \mathrm{dL} \text {. Statistical } \\
\text { analysis results with Complete Randomized Design (RAL) revealed } \\
\text { that positive control group, infusion in } 1 \% \text { and } 2 \% \text { dose did not have a } \\
\text { significant difference with normal controls, that means allopurinol and } \\
\text { both doses test give an effect to return the uric acid to normal conditions. } \\
\text { Conclusion: The ripe Kersen's (Muntingia Calabura) fruit skin infusion } \\
\text { provides a reduction effect on blood uric acid levels in the rats (Rattus } \\
\text { Novergicus) that have been induced by caffeine. Concentration of infusion } \\
\text { that reduced effect of blood uric acid levels in the rats are at } 1 \% \text { ( } 1 \mathrm{~g} / 200 \\
\text { gBW) and } 2 \% \text { ( } 2 \text { g/ } 200 \text { gBW). However, the reduction is not equivalent to } \\
\text { the positive control of Allopurinol. }\end{array}$ \\
\hline
\end{tabular}

Latar Belakang: Asam urat merupakan hasil akhir dari metabolisme purin, yaitu perombakan enzimatis sel-sel tubuh dari asam dinukleotida atau asam ribonukleotida. Kadar asam urat yang tinggi dapat mengendap pada persendian sentral dan jaringan mesenkim seperti ginjal.

Tujuan Penelitian: Tujuan penelitian ini adalah untuk mengetahui efek pemberian infusa kulit buah kersen (matang) terhadap kadar asam urat pada tikus putih (rattus novergicus) yang telah diinduksi kofein.

Metode: Hewan uji yang digunakan sebanyak 18 ekor yang dibagi menjadi 6 kelompok yaitu 3 kelompok kontrol (negatif, positif, dan normal) dan 3 kelompok perlakuan (dosis 0,5\%, 1\%, dan 2\%). Pengukuran kadar asam urat darah dilakukan sebelum induksi, setelah induksi dan setelah perlakuan pada hari ke 9, 12,15 . 
Hasil: Hasil menunjukkan bahwa terjadi penurunan kadar asam urat pada tikus putih yang diberikan infusa kulit buah kersen matang pada dosis 1\% sebesar 3,43 mg/dl dan dosis $2 \%$ sebesar 3,23 mg/ $d l$, namun penurunan kadar asam urat tersebut belum setara dengan efek penurunan kontrol allopurinol yaitu sebesar 2,9 mg/dl. Hasil analisis statistik dengan Rancangan Acak Lengkap (RAL) menunjukkan kelompok kontrol positif, infusa dosis $1 \%$ dan infusa dosis 2\% tidak berbeda nyata dengan kontrol normal, artinya allopurinol dan kedua dosis uji memberikan efek untuk mengembalikan asam urat dalam kondisi normal.

Kesimpulan: Infusa kulit buah Kersen (Mutingia calabura) memberikan efek penurunan asam urat pada tikus (Rattus norvegicus) yang telah diinduksikan kafein. Konsentrasi infusa yang menurunkan kadar asam urat adalah 1\% ( 1 g/ $200 \mathrm{gBW}$ ) and 2\% (2 g/200 gBW) namun, penurunannya tidak setara dengan kontrol positif allupurinol.

\section{INTRODUCTION}

Uric acid or gout is the result of the body's metabolism, so that, its presence in the blood and urine is normal. But, when its production becomes too excessive, it can cause uric acid levels in the blood increases and settled in the central joints and mesenchymal tissues, such as the kidney. ${ }^{1}$

There is two type of pharmacotherapy drugs to reduce uric acid levels, include uricosuric and uricostatic drugs. Uricosuric drugs such as Probenecid, Sulfinpyrazone, and Benzbromarone increase the uric acid eliminations. Uricostatic drug reduces uric acid levels by inhibiting the uric acid forming enzyme (Xanthin Oxidase). Allopurinol is the only therapeutically used uricostatic drug. ${ }^{2}$ The alternative way to overcome gout disease is by using a traditional medicine which uses several types of medicinal plants containing antioxidant compounds. ${ }^{3}$

Some indonesia's Origin Medicinal Plants (OAI) content a high Flavonoid compounds, safe to used and easily obtained to prevent the uric acid formation in the body. "Kersen" or "Talok" (Muntingia calabura L.) is one of an Indonesia's Origin Medicinal Plants containing Flavonoid. ${ }^{4}$

Based on the description above, need to be conducted a research to verify an effect of Kersen's ripe skin infusion to decrease uric acid levels in blood by using the rats (Rattus novergicus) as an animal test.

\section{METHODS}

\section{Sampling Preparation}

Ripe fruits of Kersen were collected from Perumahan Departemen Agama Makassar, Sulawesi Selatan. The initial stage in sampling preparation included washing, sorting, and stripping processto take only the skin of kersen fruit.

\section{Infusion Preparation}

Infusion was prepared in three variations of concentration i.e. 0,5\% (500 mg/ $200 \mathrm{gBW})$, $1 \%(1 \mathrm{~g} / 200 \mathrm{gBW})$ and $2 \%$ ( $2 \mathrm{~g} / 200 \mathrm{gBW})$. a $0,5 \%$ concentration was started by adding 100 $\mathrm{mL}$ Aquadest to $500 \mathrm{mg}$ Kersen's skin in the infusion pot. After some aquadest was added twice as much as the Kersen's skin weight, the infusion were heated for fifteen minutes (start counting when the temperature reaches $90^{\circ} \mathrm{C}$ while stirring it at the same time). Then, the infusion was covered by flannel while it was hot. This similar procedure was applied to make $1 \%$ and $2 \%$ concentration by using $1 \mathrm{~g}$ and $2 \mathrm{~g}$ Kersen's ripe skin powder.

\section{Preparation of allopurinol suspension}

Manucturing of an allopurinol suspension was performed by adding an allopurinol powder into the developed $0,5 \%$ of Na-CMC solution. Crush it to homogeneous then add $15 \mathrm{ml}$ Aquadest. ${ }^{5}$

\section{Gout inducing}

Increasing uric acid level was performed by inducing caffeine suspension orally at $27 \mathrm{mg}$ dose for six days.

\section{Animal test treatment}

Eighteen rats were applied in this research as an animal test (subject). Firstly, subjects were adapted with a research environment for two weeks with a new environment. During the adaptation process, conducted an observation of 
subject general conditions and weight weighing.

Furthermore, rats were divided into six groups; each group consisting of three mice, wherein the first treatment was administering $\mathrm{Na}$-CMC solution as a normal control, caffeine 27 $\mathrm{mg} / 200 \mathrm{gBW}$ in $1 \% \mathrm{Na}-\mathrm{CMC}$ as negative control, and 5,4 mg/200 gBW Allopurinol suspension with $27 \mathrm{mg} / 200 \mathrm{gBW}$ of caffeine suspension as a positive control, and the infusion control of the Kersen's skin is performed in three treatments i.e. $27 \mathrm{mg} / 200 \mathrm{gBW}$ of caffeine suspension and doses infusion in $0,5 \%, 1 \%$ and $2 \%$.

In Testing Phase, the effort to increase uric acid levels has been done by inducing the rats with $27 \mathrm{mg} / 200 \mathrm{~g}$ BB of caffeine. After that, mice's blood uric acid levels were controlled and measured at the zero ( 0 ) day to convince the induction caused hyperuricemia. Then, all the rats were saved in their cages and got the feeding and drinking as usual. On the first day after treatment, the rats were treated in their every group every day. Themeasurement of the mice's blood uric acid levels was done on the third (3rd), sixth (6th) and ninth (9th) days after treatments.

\section{Blood uric acid measurement}

Before the blood collection process, the rats were swabbed by ethanol $70 \%$. Blood was taken by injuring or cutting the mice's tail with a small knife (cutter). Then, the blood was dripped on the uric acid strip.

Blood uric acid levels were measured by using a uric acid strip kit, an Easy Touch GCU (Glucose, Cholesterol, Uric Acid). GCU is designed for quantitative measurements of uric acid levels in the blood based on the determination of the current changes which caused by the uric acid reaction with the reagent on the strip electrode. When the blood reaches the target sample area on the strip, the blood automatically is drawn into the reaction zone of the strip. The results will be displayed on the screen after twenty (20) seconds.

\section{Data Analysis}

Data analysis that obtained in this research in the form of blood uric acid levels were analysed into a Variance Analysis (ANOVA) for a Completely Randomized Design (RAL) with unequal replications at the $5 \%$ significance level. If $\mathrm{P}<0,01,0,05$, will continued the follow-up test based on the coefficient of diversity.

\section{RESULTS}

This research used the ripe Kersen's (Muntingia calabura) fruit skin infusion with three variants of concentration i.e. 0,5\% (500 $\mathrm{mg} / 200 \mathrm{gBW}$ ), 1\% (1 g / $200 \mathrm{gBW}$ ) and 2\% (200 mg / $200 \mathrm{gBW}$ ). Infusion is an extraction process which is generally used to extract an active substance in plant preparations which protracted in the water and vegetal ingredients.

On zero-day (0) before induced by caffeine, the initial measurement of blood uric acid level was done to find out all ratgroups revealed normal levels. Then, on the 6th day, rats have primary hyperuricemia after caffeine induction for six days.. On seventh days, the treatment was given based on each group - performed similar treatment for nine days. After that, blood uric acid levels are measured on the 9th, 12th day until the final measurement on 15 th.

Table 1. The results of average levels of Uric Acid During Experiments (mg/dL).

\begin{tabular}{llllll}
\hline $\begin{array}{c}\text { Period } \\
\text { (day) }\end{array}$ & $\begin{array}{c}\text { Negative } \\
\text { control group }\end{array}$ & $\begin{array}{c}\text { Control } \\
(5 \%)\end{array}$ & $\begin{array}{c}\text { Control (1\%, 1 } \\
\text { g / 200 gBW) }\end{array}$ & $\begin{array}{c}\text { Control (2\%,2 } \\
\text { g / 200 gBW) }\end{array}$ & $\begin{array}{c}\text { Positive } \\
\text { control group }\end{array}$ \\
\hline 0 & 3,13 & 2,87 & 3,00 & 2,93 & 2,43 \\
6 & 4,87 & 4,17 & 3,87 & 4,17 & 4,03 \\
15 & 7,13 & 5,33 & 3,43 & 3,23 & 2,90 \\
\hline
\end{tabular}

The table 1 shows the average of initial blood uric acid level on the zero-day, on sixth day (after induced by caffeine), and on fifteenth day 15 (after treatment). 


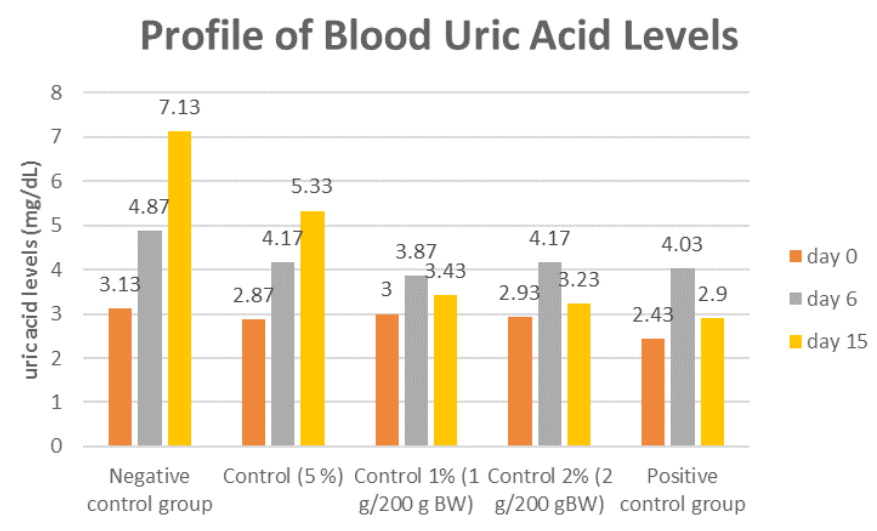

Figure.1 The graphic of the average value of uric acid Level

The graphic reveals that positive control group (Allopurinol) had a uric acid level higher than control dose of $1 \%$ group ( $1 \mathrm{~g} / 200 \mathrm{gBW}$ ) and control dose of $2 \%$ group ( $2 \mathrm{~g} / 200 \mathrm{gBW}$ ). These results showed that the infusion of ripe kersen fruit at a dose of $2 \%$ ( $2 \mathrm{~g} / 200 \mathrm{gBW})$ and a dose of $1 \%(1 \mathrm{~g} / 200 \mathrm{gBW})$ could reduce uric acid levels in the blood but did not equivalent to the positive control group (Allopurinol). In addition, the group dose of 0,5\% (500 mg /
$200 \mathrm{gBW}$ ) was not affected by decreasing uric acid levels.

Determining the comparison of decreasing of uric acid levels between the groups, analysis of Variance (ANOVA) method was carried out for Completely Randomized Design (CRD) with unequal replications at the significance level $\alpha=0,05$. The data of uric acid levels on the fifteenth day were taken from all treatment groups for analysis.

Table 2. The analysis of variance (ANOVA) of the effect of treatment in uric acid levels after induced for 15 days

\begin{tabular}{lccccc}
\hline \multirow{2}{*}{ Groups } & \multicolumn{2}{c}{ Uric Acid Levels (mg/dL) } & Day Of 15* & \multirow{2}{*}{ Total } & \multirow{2}{*}{ Mean } \\
\cline { 2 - 5 } & \multicolumn{1}{c}{$\mathbf{1}$} & $\mathbf{2}$ & $\mathbf{3}$ & & \\
\hline Normal group & 2,0 & 2,2 & 2,4 & 6,6 & 2,20 \\
Negative group & 6,8 & 6,3 & 8,3 & 21,4 & 7,13 \\
Control (0,5\%) & 5,2 & 5,5 & 5,3 & 16 & 5,33 \\
Control (1\%) & 3,2 & 3,6 & 3,5 & 10,3 & 3,43 \\
Control (2\%) & 3,5 & 2,4 & 3,8 & 9,7 & 3,23 \\
Positive control group (Allopurinol) & 2,6 & 2,8 & 3,3 & 8,7 & 2,90 \\
Total & 23,30 & 22,80 & 26,60 & 72,70 & 24,23 \\
Mean & 3,88 & 3,80 & 4,43 & 12,12 & 4,04 \\
SD & & & & & 1,84 \\
\hline
\end{tabular}

*replicated measurements 
Table 3. Analysis of variance (ANOVA) of the effect of treatment in uric acid levels after induced for 15 days

\begin{tabular}{|c|c|c|c|c|c|c|}
\hline \multirow{2}{*}{ SK } & \multirow{2}{*}{$\begin{array}{l}\text { Degree of } \\
\text { Freedom }\end{array}$} & \multirow{2}{*}{$\begin{array}{l}\text { Number of } \\
\text { quadrant }\end{array}$} & \multirow{2}{*}{$\begin{array}{l}\text { Quadrant } \\
\text { count }\end{array}$} & \multirow{2}{*}{$F_{\text {count }}$} & \multicolumn{2}{|c|}{$\mathbf{F}_{\text {Table }}$} \\
\hline & & & & & $\mathrm{Ft}_{\mathbf{0 , 0 5}}$ & $\mathrm{Ft}_{0,01}$ \\
\hline Treatment & 5 & 50,84 & 10,168 & $32,08^{* *}$ & 3,11 & 5.06 \\
\hline Galat & 12 & 3,73 & 0,310 & - & - & - \\
\hline Total & 17 & 54,57 & - & - & - & - \\
\hline
\end{tabular}

** : Significantly

According to the data analysis above, treatment groups affected significantly based on value of $\mathrm{F}_{\text {count }}>\mathrm{F}_{\text {table }}$ at significant level $5 \%$ and $1 \%$. The investigation continued to Least Significance Difference (LSD) as post hoc test to ensure the difference between groups.

The LSD Analysis showed that there was significant difference uric acid levels between all control dose groups of extract infusion and positive control groups with the negative control group so that allopurinol and all control dose groups of extract infusion had effect in coffeininduced rats.

\section{DISCUSSION}

The positive control group were not significantly different to normal control, meaning that allopurinol can restore gout in normal conditions. The control group dose of $2 \%$ (2 g / 200 gBW) 1\% (1 g / 200 gBW) were not significantly different from the positive control at the test level of 5\%. The control group dose of $2 \%$ ( $2 \mathrm{~g} / 200 \mathrm{gBB}$ ) and 1\% (1 g / $200 \mathrm{gBB})$ had an effect on decreasing uric acid levels but was not comparable with the positive control (Allopurinol). Kersen fruit juice was able to reduce blood uric acid levels of male Wistar rats induced by potassium oxonate, but the decreasing levels were not equivalent to normal control (Allopurinol). ${ }^{6}$

The mechanism for reducing uric acid levels in this study is not yet known. The effect of lowering uric acid levels from ripe Kersen fruit skin infusions is thought to be due to the inhibition of enzyme activity of xanthine oxidase by flavonoids as has been done in previous studies or can be caused by an increase in excreting urine or a combination of both. Therefore, it is necessary to do further research on the mechanism of reducing uric acid levels by administering ripe Kersen fruit skin infusion. Uric acid levels increase depending on the causes. A high purine diet can trigger hyperuricemia in people who have congenital abnormalities in purine metabolism increasinguric acid production. Treatment of hyperuricemia is an attempt to minimise uric acid production or increase uric acid excretion by the kidneys. The drug allopurinol works to reduce the formation of uric acid by inhibiting xanthine oxidase, an enzyme that converts hypoxanthine to xanthin which then becomes gout. ${ }^{2,7}$

\section{CONCLUSION}

The ripe Kersen's (Muntingia calabura) fruit skin infusion provides a reduction effect on blood uric acid levels in the rats (Rattus novergicus) that have been induced by caffeine. Concentration of infusion that reduced effect of blood uric acid levels in the rats are at $1 \%(1 \mathrm{~g} / 200 \mathrm{gBB})$ and $2 \%(2 \mathrm{~g} / 200 \mathrm{gBW})$. However, the reduction is not equivalent to the positive control of Allopurinol.

\section{CONFLICT OF INTEREST}

Non Declared

\section{Acknowledgement}

We greatly appreciate the contribution of Akademi Farmasi (AKFAR) Kebangsaan as provider of our research facilities. 
We are grateful to expert reviewers for the contribution the make.

\section{REFERENCES}

1. Alexander D, Alam G, Kondar W. Pengaruh ekstrak rimpang temu Putih (Curcuma zedoaria) terhadap kadar asam urat pada kelinci. Majalah Farmasi dan Farmakologi. 2011;15(2):89-94.

2. Ellen MM, Caroline FT, John TC, Russ B, Teri EK. PharmGKB summary: Uric acid-lowering drugs pathway, pharmacodynamics. Pharmacogenetics and Genomics. 2014;24(9):464-76.

3. Muhtadi, Wahyuningtyas N, Syahprawira Y, Suhendi A. Penghambatan xantin Oosidase oleh kombinasi ekstrak Jinten Hitam (Nigella sativa L.)., Meniran (Phyllanthus niruri L.), dan Tempuyung (Sonchus ArvensisL.) pada mencit hiperurisemia. Symposium Nasional Kimia Bahan Alam. 2015;10-1.

4. Ida Kholifaturrokhmah, Ratna Damma Purnawati. Pengaruh pemberian esktrak buah (Muntingia calabura L.) dosis bertingkat terhadap gambaran histopatologi ginjal mencit BALB/C yang hiperurisemia. Jurnal Kedokteran Diponegoro. 2015;5(3).

5. Dewi Astuti. Efek antihiperurisemia ekstrak air kombinasi kelopak Rosella (Hibiscus sabdariffa L) dan akar tanaman akar kucing (Acalypha indica L) pada tikus putih jantan yang diinduksi kalium oksonat. Universitas Indonesia; 2011.

6. Meiliza ER. Pengaruh jus buah Kersen (Muntingia calabura L.) terhadap kadar asam urat darah mencit (MusMusculus). Universitas Muhammadiyah Surakarta; 2013.

7. Micaela G, Natalia M, Saverio M, Vincenzo M. The treatment of hyperuricemia. International Journal of Cardiology. 2016;213:237. 